\title{
Influence of proliferation signal inhibitors on vascular endothelial growth factor production in heart transplant recipients - preliminary report
}

\author{
Natalia Kamieńska ${ }^{1}$, Michał Zakliczyński ${ }^{1,2}$, Alicja Kasperska-Zając ${ }^{3}$, Marta Szewczyk ${ }^{4}$, \\ Dominika Trybunia-Orzeszek ${ }^{5}$, Jerzy Nożyński ${ }^{6}$, Marta Pijet ${ }^{6,7}$, Tomasz Hrapkowicz ${ }^{1}$, Marian Zembala ${ }^{1,2}$
}

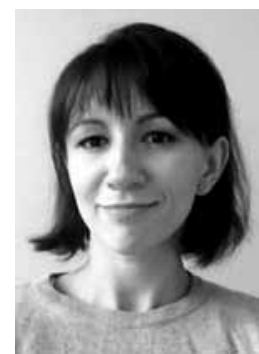

${ }^{1}$ Department of Cardiac Surgery and Transplantation, Medical University of Silesia in Katowice, School of Medicine with the Division of Dentistry in Zabrze, Silesian Center for Heart Diseases, Zabrze, Poland

${ }^{2}$ Department of Heavy Cardiopulmonary Respiratory Failure and Mechanical Circulatory Support, Silesian Center for Heart Diseases, Zabrze, Poland

${ }^{3}$ Department of Internal Medicine, Dermatology and Allergology, Medical University of Silesia in Katowice, School of Medicine with the Division of Dentistry in Zabrze, Specialist Hospital in Zabrze, Poland

${ }^{4}$ Laboratory of Monitoring Medicines, Silesian Center for Heart Diseases, Zabrze, Poland

${ }^{5}$ Department of Internal, District Hospital, Radomsko, Poland

${ }^{6}$ Department of Histopathology, Silesian Center for Heart Diseases, Zabrze, Poland

${ }^{7}$ Doctoral School, Medical University of Silesia in Katowice, School of Pharmacy with the Unit of Medical Analytics

in Sosnowiec, Poland

Kardiochirurgia i Torakochirurgia Polska 2014; 11 (2): 173-177

\begin{abstract}
Proliferation signal inhibitors (PSI) are especially beneficial for heart transplant recipients, but are rarely used due to frequent side effects. As they may be caused by vascular endothelial growth factor (VEGF), we performed a prospective cross-sectional pilot study to assess the influence of PSI and/ or calcineurin inhibitors (CNI) presence in immunosuppressive protocols of heart transplant recipients on VEGF secretion. All electively screened heart transplant recipients willing to participate were enrolled in the study. The preliminary report was based on the results of the first 89 serum samples. The study group $(n=84)$ consisted of the PSI group $(n=14)$ further divided into the PSI + CNI subgroup $(n=10)$ and PSIw/oCNI subgroup $(n=4)$ based on concomitant CNI use, and the CNIw/ oPSI group $(n=70)$ receiving CNI without PSI. The control group $(n=5)$ consisted of patients not requiring immunosuppression. VEGF was present in serum of 70 (83\%) study group patients: median (range) $18(0-316) \mathrm{pg} / \mathrm{mL}$, mean $35 \pm 57 \mathrm{pg} / \mathrm{mL}$; in 13 (93\%) PSI group patients: $22(0-110) \mathrm{pg} / \mathrm{mL}, 28 \pm 28 \mathrm{pg} / \mathrm{mL}$, with $19(8-20) \mathrm{pg} / \mathrm{mL}, 16 \pm 6 \mathrm{pg} / \mathrm{mL}$ in the PSI+CNI subgroup, and $29(0-110) \mathrm{pg} / \mathrm{mL}, 32 \pm 32 \mathrm{pg} / \mathrm{mL}$ in the PSIw/oCNI subgroup. In the CNIw/oPSI group VEGF was present in 57 (81\%) patients: $16(0-316) \mathrm{pg} / \mathrm{mL}, 37 \pm 62 \mathrm{pg} / \mathrm{mL}$, and in the control group in $3(60 \%)$ patients: $4(0-110) \mathrm{pg} / \mathrm{mL}, 32 \pm 48 \mathrm{pg} / \mathrm{mL}$. None of the differences observed between any compared groups and/or subgroups was significant $\left(\chi^{2}\right.$ and Mann-Whit-
\end{abstract}

\section{Streszczenie}

Inhibitory sygnału proliferacji (proliferation signal inhibitors - PSI) wykazują szczególne korzyści w terapii pacjentów po transplantacji serca, jednak ich stosowanie ograniczają częste działania uboczne. Ponieważ powodem pojawiania się tych działań może być czynnik wzrostu śródbłonka naczyniowego (vascular endothelial growth factor - VEGF), przeprowadzono przekrojowe prospektywne badanie pilotażowe, którego celem była ocena zależności pomiędzy obecnością PSI i/lub inhibitorów kalcyneuryny (CNI) w protokołach immunosupresyjnych pacjentów po transplantacji serca a stężeniem VEGF. Badanie zaplanowano u wszystkich pacjentów po transplantacji serca poddawanych planowym badaniom kontrolnym, wyrażającym zgodę na udział. Doniesienie wstępne przygotowano po oznaczeniu VEGF w pierwszych 89 próbkach. W grupie badanej ( $n=84)$ wyróżniono grupę chorych otrzymujących PSI $(n=14)$ dalej podzieloną na podgrupy PSI + CNI $(n=10)$ i PSIw/oCNI ( $n=4)$ w zależności od tego, czy przyjmowali oni CNI, oraz grupę CNIw/oPSI $(n=70)$ otrzymującą CNI bez PSI. Pięciu pacjentów niewymagających immunosupresji stanowiło grupe kontrolną. Obecność VEGF stwierdzono w surowicy 70 (83\%) pacjentów z grupy badanej: mediana (zakres) 18 (0-316) pg/ml, średnia $35 \pm 57$ pg/ml. W grupie PSI VEGF był obecny u 13 (93\%) pacjentów: mediana (zakres) $22(0-110)$ pg/ml, średnia $28 \pm 28$ $\mathrm{pg} / \mathrm{ml}$, przy czym pogrupa PSI + CNI uzyskała odpowiednio 19 $(8-20) \mathrm{pg} / \mathrm{ml}$ i $16 \pm 6 \mathrm{pg} / \mathrm{ml}$, a podgrupa PSIw/oCNI $29(0-110)$

Address for correspondence: Prof. Michał Zakliczyński, Department of Cardiac Surgery and Transplantation, Medical University of Silesia in Katowice, School of Medicine with the Division of Dentistry in Zabrze, Silesian Center for Heart Diseases, 41800 Zabrze, Sklodowskiej 9 , Poland, tel. +48 5160731 46, e-mail: zaklimed@onet.pl 
ney $U$ test). In conclusion, differences of VEGF concentration observed among groups imply the influence of PSI and CNI on VEGF production, but further studies involving higher numbers of participants are needed to prove it.

Key words: heart transplantation, proliferation signal inhibitors, everolimus, sirolimus, vascular endothelial growth factor.

\section{Introduction}

Proliferation signal inhibitors (PSI), represented by sirolimus (SIR) and its analog everolimus (EVE), constitute a group of immunosuppressive drugs used in heart and other solid organ transplant recipients [1, 2]. While in heart recipients PSI are indicated predominantly to facilitate dose reduction or withdrawal of calcineurin inhibitors (CNI) in the presence of its nephrotoxicity [3, 4], they not only affect acute rejection but also prevent early development of cardiac allograft vasculopathy (CAV) by slowing intimal hyperplasia [5-8]. Despite this, the majority of transplant physicians and patients are reluctant to use PSI due to common adverse side effects, including dermatological lesions, impaired wound healing, stomatitis, interstitial pneumonitis, thrombocytopenia, proteinuria and metabolic disorders: hyperglycemia and dyslipidemia $[9,10]$.

Unlike CNI, PSI do not influence the secretion of interleukin-2 (IL-2), but inhibit the response of lymphocytes to IL-2 by binding to an intracellular protein, FKBP-12, forming a complex that inhibits the mammalian target of rapamycin (mTOR) serine-threonine kinase, and thereby blocking the transmission of the proliferation signal to the nucleus of the $T$ cell $[11,12]$. The same mechanism of action occurs when PSI are administered due to oncological indications, but this time it is a disruption of the signal from the membrane receptor for vascular endothelial growth factor (VEGF) that protects vascularization of the neoplasm $[13,14]$.

VEGF should be considered a family of proteins involved in new endothelial cell formation, migration and activation, stem cell recruitment, and tissue regeneration. Five subtypes of VEGF have been identified from $A$ to $D$, and placental growth factor. The downstream signals of VEGFs are mediated by tyrosine kinase receptors VEGFR-1, VEGFR-2 and VEGFR-3. Formation of new vessels depends on VEGF-A and VEGF-B binding to VEGFR-1 and -2. VEGFR-3 is associated with development of the lymphatic system [15]. Interestingly, VEGF is also thought to be responsible for some dermatoses that belong to frequent side-effects of PSI common for oncologic and transplant patients [16].

We hypothesize that VEGF may play an important role in development of PSI side-effects in heart transplant recipients. As a first step to investigate this supposition we performed this pilot cross-sectional study to evaluate the $\mathrm{pg} / \mathrm{ml}$ i $32 \pm 32 \mathrm{pg} / \mathrm{ml}$. W grupie CNIw/oPSI VEGF stwierdzono u 57 (81\%) pacjentów: mediana (zakres) 16 (0-316) pg/ml, średnia $37 \pm 62 \mathrm{pg} / \mathrm{ml}$, a w grupie kontrolnej u 3 (60\%) pacjentów: odpowiednio 4 (0-110) pg/ml, $32 \pm 48$ pg/ml. Różnice obserwowane między grupami nie były istotne statystycznie (testy $\chi^{2}$ i U Manna-Whitneya). Podsumowując, różnice pomiędzy stężeniami VEGF w poszczególnych grupach wskazują na to, iż jego wytwarzanie podlega wpływom leków immunosupresyjnych z grup PSI i CNI, jednak udowodnienie tej relacji wymaga kontynuacji badań z udziałem większej liczby uczestników.

Słowa kluczowe: transplantacja serca, inhibitory sygnału proliferacji, ewerolimus, sirolimus, czynnik wzrostu śródbłonka naczyniowego.

influence of different immunosuppressant protocols, containing PSI and/or CNI, on VEGF production.

\section{Material and methods}

This research was designed as a prospective crosssectional study involving all heart transplant recipients remaining under in- and outpatient care of our center willing to participate. Blood samples were obtained at the time of the elective outpatient visit (scheduled at least every 6 months), or during hospitalization undertaken to perform endomyocardial biopsy or coronary angiography. The first 84 heart transplant recipients enrolled to prepare this interim report constituted the study group. Additionally, 5 non-transplant patients of the outpatient clinic agreed to participate as the control group.

The study group was divided into several subgroups according to the patients' immunosuppressive protocol: the $\mathrm{PCl}$ group $(n=14)$ with patients receiving EVE or SIR was further divided into PSI $+\mathrm{CNI}(n=4)$ composed of patients receiving $\mathrm{PSI}$ and $\mathrm{CNI}$ (cyclosporine-A or tacrolimus) concomitantly, PSIw/oCNI $(n=10)$ receiving CNI-free immunosuppression, and CNIw/oPSI $(n=70)$ containing patients treated with cyclosporine-A or tacrolimus without PSI. Basic characteristics of the study and control groups are presented in Table I.

PSI and CNI doses were determined based on trough levels monitoring in the whole blood according to the following target ranges: EVE - 3-8 ng/mL with CNI, and 8-12 ng/mL without CNI; SIR - 8-12 ng/mL with CNI, and 12-20 ng/mL without CNI; cyclosporine-A - below $100 \mathrm{ng} /$ $\mathrm{mL}$ with PSI, and over $100 \mathrm{ng} / \mathrm{mL}$ without PSI; tacrolimus - below $7 \mathrm{ng} / \mathrm{mL}$ with PSI later than 12 months after the surgery, 7-10 ng/mL with PSI within the first 12 months after the surgery, or without PSI thereafter, and $10-15 \mathrm{ng} / \mathrm{mL}$ without PSI during the $1^{\text {st }}$ year after heart transplantation. The majority of patients from PSIw/oCNI and CNIw/oPSI groups received mycophenolate mofetil, which was dosed according to the serum trough level in order to achieve the target range of $1.5-2.0 \mu \mathrm{g} / \mathrm{mL}$.

Serum samples to assess VEGF concentration were collected at the time of elective visits after centrifugation of a $5 \mathrm{~mL}$ whole blood sample and immediately frozen and stored at $-80^{\circ} \mathrm{C}$. Further assessment was performed using 
Tab. I. Description of the study and control group

\begin{tabular}{|c|c|c|c|c|c|c|}
\hline & $\begin{array}{l}\text { Study } \\
\text { group }\end{array}$ & $\begin{array}{l}\text { PSI } \\
\text { group }\end{array}$ & $\begin{array}{l}\text { PSI + CNI } \\
\text { subgroup }\end{array}$ & $\begin{array}{l}\text { PSIw/oCNI } \\
\text { subgroup }\end{array}$ & $\begin{array}{l}\text { CNIw/oPSI } \\
\text { group }\end{array}$ & $\begin{array}{l}\text { Control } \\
\text { group }\end{array}$ \\
\hline Number of patients & 84 & 14 & 4 & 10 & 70 & 5 \\
\hline Age (years) & $50 \pm 17$ & $57 \pm 12$ & $53 \pm 14$ & $58 \pm 11$ & $49 \pm 18$ & $36 \pm 13$ \\
\hline Gender (M\%/F\%) & $73 / 27$ & $64 / 36$ & $100 / 0$ & $90 / 10$ & $74 / 26$ & $60 / 40$ \\
\hline Indication for OHT (CAD\%/nCAD\%) & $34 / 66$ & $64 / 36$ & $50 / 50$ & $30 / 70$ & $36 / 64$ & - \\
\hline Donor age (years) & $32 \pm 11$ & $38 \pm 8$ & $34 \pm 6$ & $40 \pm 9$ & $31 \pm 11$ & - \\
\hline Donor/recipient gender match (Y\%/N\%) & $66 / 35$ & $67 / 33$ & $0 / 100$ & $89 / 11$ & $73 / 27$ & - \\
\hline Ischemic time (minutes) & $170 \pm 54$ & $189 \pm 69$ & $192 \pm 45$ & $188 \pm 77$ & $167 \pm 50$ & - \\
\hline
\end{tabular}

$\mathrm{PSI}$ - proliferation signal inhibitors, $\mathrm{CNI}$ - calcineurin inhibitors, w/o - without, $\mathrm{M}$ - male, $\mathrm{F}$ - female, OHT - orthotopic heart transplantation, $\mathrm{CAD}$ - coronary artery disease, $\mathrm{nCAD}$ - no coronary artery disease, $\mathrm{Y}$ - yes/positive, $\mathrm{N}$ - no/negative

the Quantikine Human VEGF Immunoassay, employing the quantitative sandwich enzyme immunoassay technique. A monoclonal antibody specific for VEGF was pre-coated onto a microplate. Standards and samples were pipetted into the wells and any VEGF present was bound by the immobilized antibody. After washing away any unbound substances, an enzyme-linked polyclonal antibody specific for the reagent, a substrate solution was added to the wells and color developed in proportion to the amount of VEGF bound in the initial step. The color development was stopped and the intensity of the color was measured by absorbance at $450 \mathrm{~nm}$, with the correction wavelength set at $540 \mathrm{~nm}$ or $570 \mathrm{~nm}$. Calculation of results of the average absorbance values for each set of duplicate standards and samples was performed by the computer using a fourparameter logistic (4-PL) curve fit.

Results are presented as median and range, as well as mean \pm standard deviation. Statistical analysis was performed using non-parametric tests.

\section{Results}

VEGF was detected in 70 samples (83\%) from the study group patients and 3 samples (60\%) from control group participants. VEGF was present in all 4 patients from the PSI+CNI subgroup, followed by 13 (93\%) patients in the PSI group, 9 (90\%) patients in the PSIw/oCNI subgroup, and 57 (81\%) patients from the CNIw/oPSI group. All differences between groups and/or subgroups were insignificant ( $\chi^{2}$ test).

VEGF median concentration in the study group was higher than in the control group, and among heart transplant patients it was the highest in the PSIw/oCNI subgroup, intermediate in the PSI + CNI subgroup, and lower in the CNIw/oPSI group; however, the differences were insignificant (Mann-Whitney $U$ test). Median and mean values are presented in Figures 1 and 2.

\section{Discussion}

Our expectation, based on the basic knowledge of physiologic feedback rules of regulatory molecules secre-

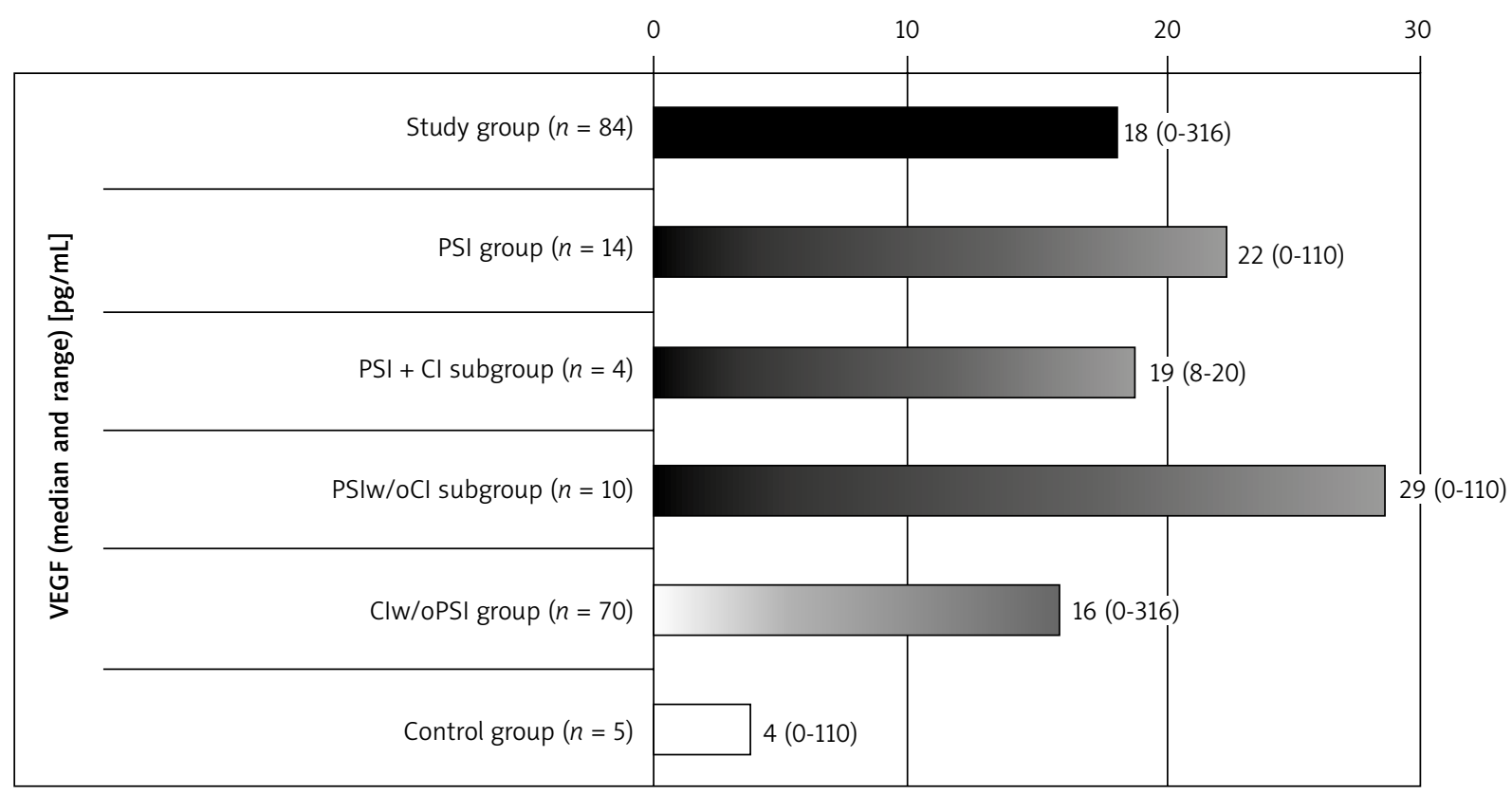

Fig. 1. VEGF serum concentrations $[\mathrm{pg} / \mathrm{mL}]$ - medians and ranges 


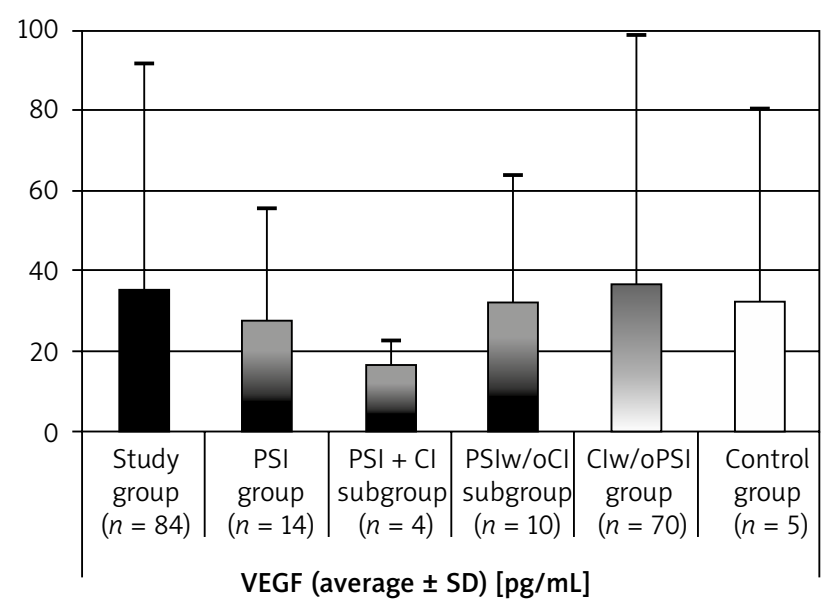

Fig. 2. VEGF serum concentrations $[\mathrm{pg} / \mathrm{mL}]-$ means and standard deviations

tion, was confirmed with the results of VEGF measurement obtained for patients receiving or not receiving PSI. The highest serum concentration was observed in the PSIw/oCNI group, lower in the CNIw/oPSI group, and intermediate in the PSI + CNI group. A less obvious observation is that VEGF in the control group was lower than in the CNIw/oPSI group. However, it should be underlined at this point that all groups (possibly except CNIw/oPSI) were underpowered to achieve the statistical proof of significance when differences between groups and/or subgroups are considered. The low number of participants, especially receiving PSI, is the main limitation of the current analysis. Despite this, the current results warrant further investigation based on a higher number of observations.

Due to the low number of enrolled patients it was not possible to address the relation of VEGF with acute rejection $[17,18]$ and cardiac allograft vasculopathy $[19,20]$ described in the literature. In both cases a significant positive correlation was described. It should also be mentioned that gene expression profiling, which is becoming a more and more popular method to describe the pathology of transplanted organs, also suggests that VEGF may play an important role, at least, in acute rejection of the transplanted heart [21]. We plan to look for correlations between VEGF and rejection in the multiplied study group. Additionally, the potential influence of age, diabetes, lipid abnormalities and statin use on VEGF concentration should also be a subject of analysis performed in a statistically sufficient group of heart transplant recipients. Last, but not least, the possibility of VEGF relation with cytomegalovirus infection in the population protected by PSI is a very interesting scientific question, especially in the context of controversies around this issue [22].

Finally, for the same reason of the low number patients receiving PSI involved in this pilot study, we had to postpone our attempt to find the relation between VEGF and dermatological side effects of PSI. This important problem observed in heart transplant recipients still awaits a focused study. At the moment, the influence of a VEGF involving mechanism in development of skin complications has been widely described comprehensively only in the group of oncologic patients [23-25].

\section{References}

1. Eisen H, Kobashigawa J, Starling RC, Valantine H, Mancini D. Improving outcomes in heart transplantation: the potential of proliferation signal inhibitors. Transplant Proc 2005; 37 (4 Suppl): 4S-17S.

2. Hirt SW, Bara C, Barten MJ, Deuse T, Doesch AO, Kaczmarek I, Schulz U, Stypmann J, Haneya A, Lehmkuhl HB. Everolimus in Heart Transplantation: An Update. J Transplant 2013; 2013: 683964. Epub 2013 Dec 5.

3. Engelen MA, Welp HA, Gunia S, Amler S, Klarner MP, Dell'aquila AM, Stypmann J. Prospective Study of Everolimus With Calcineurin Inhibitor-Free Immunosuppression After Heart Transplantation: Results at Four Years. Ann Thorac Surg 2013 Nov 6. pii: S0003-4975

4. Gonzalez-Vilchez F, Vazquez de Prada JA, Paniagua MJ, Gomez-Bueno M, Arizon JM, Almenar L, Roig E, Delgado J, Lambert JL, Perez-Villa F, SanzJulve ML, Crespo-Leiro M, Segovia J, Loper-Granados A, Martinez-Dolz L, Mirabet S, Escribano P, Diaz-Molina B, Farrero M, Blasco T. Use of mTOR inhibitors in chronic heart transplant recipients with renal failure: Calcineurin-inhibitors conversion or minimization? Int J Cardiol 2013 Nov 23. pii: S0167-5273(13)02054-8.

5. Masetti M, Potenta L, Nardozza M, Prestinenzi P, Taglieri N, Saia F, Pece V, Magniani G, Fallani F, Cocolo F, Russo A, Rapezzi C, Grigioni F, Branzi A. Differential effect of everolimus on progression of early and late cardiac allograft vasculopathy in current clinical practice. Am J Transplant 2013; 13: 1217-1226.

6. Arora S, Erikstad I, Ueland T, Sigurdardottir V, Ekmehag B, Jansson K, Eiskajaer H, Botker HE, Mortensen SA, Saunamaki K, Gaude E, Ragnarsson A, Solbu D, Aukrust P, Gullestad L. Virtual histology assessment of cardiac allograft vasculopathy following introduction of everolimus - results of a multicenter trial. Am J Transplant 2012; 12: 2700-2709.

7. Pinney SP, Mancini D. Cardiac allograft vasculopathy: advances in understanding its pathophysiology, prevention, and treatment. Curr Opin Cardiol 2004; 19: 170-176.

8. Matsuo Y, Cassar A, Yoshino S, Flammer AJ, Li J, Gulati R, Topilsky Y, Raichlin E, Lennon RJ, Lerman LO, Rihal CS, Kushwaha SS, Lerman A. Attenuation of cardiac allograft vasculopathy by sirolimus: Relationship to time interval after heart transplantation. J Heart Lung Transplant 2013; 32: 784-791.

9. Gonzalez-Vilchez F, Vazquez de Prada JA, Almenar L, Arizon Del Prado JM, Mirabet S, Diaz-Molina B, Delgado JF, Gomez-Bueno M, Paniagua MJ, PerezVilla F, Roig E, Martínez-Dolz L, Brossa V, Lambert JL, Segovia J, Crespo-Leiro MG, Ruiz-Cano MJ. Withdrawal of proliferation signal inhibitors due to adverse events in the maintenance phase of heart transplantation. J Heart Lung Transplant 2012; 31: 288-295.

10. Ensor CR, Doligalski CT. Proliferation signal inhibitor toxicities after thoracic transplantation. Expert Opin Drug Metab Toxicol 2013; 9: 63-77.

11. Kuo CJ, Chung J, Fiorentino DF, Flanagan WM, Blenis J, Crabtree GR. Rapamycin selectively inhibits interleukin-2 activation of p70 S6 kinase. Nature 1992; 358: 70-73.

12. Sánchez-Fructuoso Al. Everolimus: an update on the mechanism of action, pharmacokinetics and recent clinical trials. Expert Opin Drug Metab Toxicol 2008; 4: 807-819.

13. Cho D, Signoretti S, Regan M, Mier JW, Atkins MB. The role of mammalian target of rapamycin inhibitors in the treatment of advanced renal cancer. Clin Cancer Res 2007; 13 (2 Pt 2): 758s-763s.

14. Motzer RJ, Escudier B, Oudard S, Hutson TE, Porta C, Bracarda S, Grünwald V, Thompson JA, Figlin RA, Hollaender N, Urbanowitz G, Berg WJ, Kay A, Lebwohl D, Ravaud A; RECORD-1 Study Group. Efficacy of everolimus in advanced renal cell carcinoma: a double-blind, randomised, placebo-controlled phase III trial. Lancet 2008; 372: 449-456.

15. Taimeh Z, Loughran J, Birks EJ, Bolli R. Vascular endothelial growth factor in heart failure. Nat Rev Cardiol 2013; 10: 519-530.

16. Koczy-Baron E, Jochem J, Kasperska-Zajac A. Increased plasma concentration of vascular endothelial growth factor in patients with atopic dermatitis and its relation to disease severity and platelet activation. Inflamm Res 2012; 61: 1405-1409.

17. Abramson LP, Pahl E, Huang L, Stellmach V, Rodgers S, Mavroudis C, Backer CL, Arensman RM, Crawford SE. Serum vascular endothelial growth factor as a surveillance marker for cellular rejection in pediatric cardiac transplantation. Transplantation 2002; 73: 153-156. 
18. Bayliss J, Maguire JA, Bailey M, Leet A, Kaye D, Richardson M, Bergin PJ, Dowling J, Thomson NM, Stein AN. Increased vascular endothelial growth factor mRNA in endomyocardial biopsies from allografts demonstrating severe acute rejection: a longitudinal study. Transpl Immunol 2008; 18: 264-274.

19. Bayliss J, Bailey M, Leet A, Stein AN, Thomson NM, McLean CA. Late onset antibody-mediated rejection and endothelial localization of vascular endothelial growth factor are associated with development of cardiac allograft vasculopathy. Transplantation 2008; 86: 991-997.

20. Nykänen Al, Sandelin $H$, Krebs R, Keränen MA, Tuuminen R, Kärpänen $T$, Wu Y, Pytowski B, Koskinen PK, Ylä-Herttuala S, Alitalo K, Lemström KB. Targeting lymphatic vessel activation and CCL21 production by vascular endothelial growth factor receptor-3 inhibition has novel immunomodulatory and antiarteriosclerotic effects in cardiac allografts. Circulation 2010; 121: 1413-1422.
21. Hollander Z, Chen V, Sidhu K, Lin D, Ng RT, Balshaw R, Cohen-Freue GV, Ignaszewski A, Imai C, Kaan A, Tebbutt SJ, Wilson-McManus JE, McMaster RW, Keown PA, McManus BM; NCE CECR PROOF Centre of Excellence. Predicting acute cardiac rejection from donor heart and pre-transplant recipient blood gene expression. J Heart Lung Transplant 2013; 32: 259-265.

22. Krynicka-Mazurek A, Zakliczyński M, Nożyński J, Przybylski R, Zembala M. Successful use of cidofovir to treat refractory cytomegalovirus infection in heart transplant recipient - a case report. Kardiochirurgia Torakochirurg Pol 2012; 9: 78-81.

23. Wozel G, Sticherling M, Schön MP. Cutaneous side effects of inhibition of VEGF signal transduction. J Dtsch Dermatol Ges 2010; 8: 243-249.

24. Bonny M, Buyse V, Brochez L. Dermatological side effects of current and upcoming targeted therapies in oncology. Acta Clin Belg 2011; 66: 97-103.

25. Ishak RS, Aad SA, Kyei A, Farhat FS. Cutaneous manifestations of anti-angiogenic therapy in oncology: Review with focus on VEGF inhibitors. Crit Rev Oncol Hematol 2013 Dec 1 [Epub ahead of print]. 